\title{
IMPLEMENTATION TECHNOLOGY ACCEPTANCE MODEL (TAM) ON ACCEPTANCE OF THE ZOOM APPLICATION IN ONLINE LEARNING
}

\author{
Ahmad Faisal $\left.{ }^{1 *}\right)$, Frisma Handayanna ${ }^{2}$, Indah Purnamasari ${ }^{3}$ \\ Sistem Informasi ${ }^{1,3}$, Teknik Informatika² \\ Sekolah Tinggi Manajemen Informatika dan Komputer Nusa Mandiri \\ www.nusamandiri.ac.id \\ faisal.yume@gmail.com 1*), frisma.fha@nusamandiri.ac.id 2, indah.ihi@nusamandiri.ac.id 3 \\ $\left.{ }^{*}\right)$ Corresponding Author
}

\begin{abstract}
Abstrak
Penerapan pembelajaran online diberbagai institusi pendidikan dalam Pandemi Covid-19, memberikan dampak sikap perilaku yang mana banyak pendidik dan peserta didik juga mengeluh terbatasnya sarana teknologi, pengoperasian maupun jaringan internet di beberapa daerah atau kuota untuk mengakses pembelajaran online. Diikuti populernya aplikasi Zoom dalam menunjang pendidikan, penulis melakukan penelitian penerapan Technology Acceptance Model (TAM) terhadap penerimaan aplikasi Zoom dalam pembelajaran online guna mengetahui pengaruh penggunaan aplikasi dalam pembelajaran online dengan 4 variabel disertai pengujian hipotesis regresi linear berganda, uji-F dan uji-T memakai SPSS. Pengujian menghasilnya Perceived Usefulness, Perceived Ease of Use dan Behavioral Intention to Use mempengaruhi Actual System Usage dengan hasil yang signifikan sebesar 20,21 dan positif. Behavioral Intention to Use lebih mendominasi daripada variabel lain nilainya sebesar 5,31, sedangkan untuk yang terendah adalah Perceived Ease of Use dengan nilai $(-0,50)$.
\end{abstract}

Kata kunci: TAM, Aplikasi Zoom, Pembelajaran Online

\begin{abstract}
The application of online learning in various educational institutions in the Covid-19 Pandemic has had an impact on behavioral attitudes where many educators and students have also complained about the limited technology facilities, operations, and internet networks in some areas or quotas to access online learning. Followed by the popularity of the Zoom application in supporting education, the authors researched the application of the Technology Acceptance Model (TAM) to the acceptance of the Zoom application in online learning to determine the effect of using applications in online learning with 4 variables accompanied by multiple linear regression hypothesis testing, F-test and T-test. using SPSS. The test results in Perceived Usefulness, Perceived Ease of Use, and Behavioral Intention to Use affect Actual System Usage with significant and positive results of 20.21. Behavioral Intention to Use is more dominant than other variables with a value of 5.31, while the lowest is Perceived Ease of Use with a value of $(-0.50)$.
\end{abstract}

Keywords: TAM, Zoom Application, Online Learning

\section{INTRODUCTION}

Technology is a very important means of supporting human activities or mobility every day. The existence of information system technology makes it easier to do activities faster, more effectively, and efficiently.

There are more and more business competitions in this information system technology, both in sales, banking, education and so on. The development of information system applications that are similar in use or platforms has influenced the attitude of business people towards technology users, especially smartphones, to provide and compare other applications in terms of ease of operation, completeness of features, services, and saving internet data.

Currently, the use of information systems is increasing very rapidly, especially in the conditions of the Covid-19 Pandemic, which is by the government's appeal stating work from home, social distancing and adjustment of work systems, all activities are carried out using information technology. This also applies to the world of education by learning to teach at home through certain applications, for example in lectures, 
tutoring, and seminars conducted online according to recommended applications.

Online learning that is applied in various educational institutions ranging from elementary schools to tertiary institutions has an impact on the attitudes of parents' behavior towards their children's education. Which is doubtful about using smartphones too often and worrying about learning being used as an excuse to play smartphones or other negative things, as well as paying tuition fees online. This online learning had been implemented long before the Covid-19 pandemic, but the increase in the use of online information systems was more significant in current conditions, especially students or employees in these institutions. For this reason, an organization or agency should conduct continuous evaluations of the need to organize certain educational or training programs for employees in their work environment (Hidayat \& Junianto, 2017).

The work from home or learning from home program policy also increases internet usage. Many educators and students complain about the limited technology facilities, operations, and internet networks in some areas or quotas to access online learning. Based on the results of the 2018 APJII National Internet User Penetration survey reported from gratis. kompas.id (30 March 2020), the distribution of data shows that more than half of internet users in Indonesia are in the Java region (55.7\%), followed by Sumatra (21.6\%), Sulawesi-Maluku-Papua (10.9\%), Kalimantan (6.6\%), and Bali and Nusa Tenggara 5.2\% (Arifa, 2020).

As well as the popularity of the use of the Zoom application as a medium for meetings and education. Reporting from the page inet.detik.com (25 April 2020), the Zoom video teleconferencing service application has announced its glorious achievement by having more than 300 million daily active users (Josina, 2020). With the popularity of the Zoom application in education, the author is interested in researching the Zoom application to determine the effect of using applications in online learning according to existing constructs. And it is hoped that it can provide a better understanding of the use and benefits of the application used.

This research refers to the development of previous research with the same TAM method as in (Oktofiyani, Nurmalasari, \& Anggraeni, 2016) regarding the application of E-Learning at SMA Negeri 92 Jakarta, some factors hinder success such as infrastructure problems, the willingness of the school and students, satisfaction in using technology and so on. so that the analysis of ELearning system acceptance using the Technology
Acceptance Model (TAM) is based on the correlation coefficient of correlation, it can be concluded that the relationship that occurs between variable X (Perceived Ease to Use and Perceived Usefulness) and variable Y (Perceptions of Interest in Behavior Using Technology) The eLearning of SMA Negeri 92 Jakarta is 0.722 . The correlation value of this size is a strong positive. Here it is more about the attitude of the usage behavior, not on the effect of the real use of the application.

Regarding the application of a report card value management information system in MAN 2 Pekanbaru Model, namely, an error occurred in the input value, the data format was swapped. Using the Technology Acceptance Model (TAM) method to determine user perceptions of the information system, which consists of 3 variables, namely perceived usefulness (PU), perceived ease of use (PEU), and acceptance of IT (ACC). The result of multiple linear regression based on Unstandardized Coefficient is 4,330, and all hypotheses have a positive effect (Ramadhani \& Monalisa, 2017). It seems that more emphasis on technology is not another aspect that affects its users.

Whereas in E-learning using SIPEJAR with Technology Accepted Model (TAM) analysis resulted in perceived usefulness, perceived ease to use, and accessibility of students of the 2018 Class of Education Science in good categories with a mean score of 77.36 and a percentage of $71.63 \%$. Perceived Usefulness is in a good category with a mean score (Mean) of 26.1 and a percentage of 72.5\% (Qonita, Sulton, \& Soepriyanto, 2019). The advantages can be seen from the aspect of application accessibility aspects and the weaknesses are not towards the influence of the user. From the previous research above, the writer made this research by combining the two additional variables. Then the variables to be used are 4 variables, namely Perceived Usefulness, Perceived Ease to Use, Behavioral Intention to Use and Actual System Usage, with the aim that the expected results will be more complete and varied by emphasizing the attitude of real user behavior of the Zoom application. A description of each variable can be seen in (Herwatin et al., 2019).

It is intended that the purpose of this study is to obtain the results of the analysis of the use of the Zoom application based on the influence between constructs or variables, to provide more understanding to application users, and to apply the Technology Acceptance Model (TAM) to analyze the use and acceptance of the Zoom application in online learning. 


\section{RESEARCH METHODS}

\section{Types of research}

This research uses a quantitative approach. The quantitative approach is when the data collected is in the form of quantitative data or other types of data that can be quantified and processed using statistical techniques (Yusuf, 2017).

\section{Time and Place of Research}

This research was conducted from October to December 2020 with a case study at STMIK Nusa Mandiri branch Margonda.

\section{Research Target / Subject}

The population is taken as active students of STMIK Nusa Mandiri Odd Semester 2019/2020.

Table 1. Population Research Results

\begin{tabular}{ccc}
\hline No. & Class & Student/i \\
\hline 1 & $12.1 \mathrm{~A}$ & 18 \\
\hline 2 & $11.3 \mathrm{~A}$ & 24 \\
\hline 3 & $12.3 \mathrm{~A}$ & 20 \\
\hline 4 & $11.5 \mathrm{~A}$ & 19 \\
\hline 5 & $12.5 \mathrm{~A}$ & 31 \\
\hline 6 & $11.7 \mathrm{~A}$ & 21 \\
\hline 7 & $12.7 \mathrm{~A}$ & 33 \\
\hline 8 & $11.9 \mathrm{~B}$ & 13 \\
\hline 9 & $11.9 \mathrm{C}$ & 23 \\
\hline \multicolumn{3}{c}{ Total } \\
\hline
\end{tabular}

Meanwhile, for random sampling from active students according to population data. Based on the use of the Slovin formula, the sample calculation used is a Margin of Error of $10 \%$ or 0.1 . The calculation is: $\mathbf{n}=\mathbf{N} /\left(\mathbf{1}+\left(\mathbf{N} \times \mathbf{e}^{\mathbf{2}}\right)\right)$

$$
\begin{aligned}
& \mathrm{n}=202 /\left(1+\left(202 \times 0.1^{2}\right)\right) \\
& \mathrm{n}=202 /(1+(202 \times 0.01)) \\
& \mathrm{n}=202 /(1+2.02)=202 / 3.02=66.8
\end{aligned}
$$

If rounded, the sample size of 202 populations at a margin of error of $10 \%$ is 67 samples.

\section{Procedure}

Figure 1 represents the stages of the research carried out are as follows:

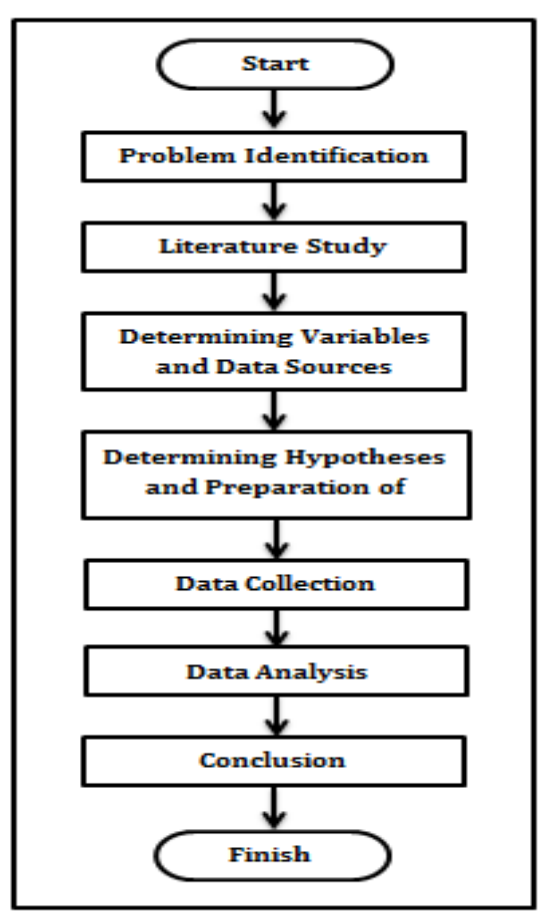

Figure 1. Research Stages

The stages:

1. Problem Identification

2. Literature study

3. Determining Variables and Data Sources

4. Determining Hypotheses and Preparation of

Questionnaires

5. Data Collection

6. Data Analysis

7. Conclusion

Data, Instruments, and Data Collection Techniques

The data collection methods in this study are as follows:

1. Observation

Direct observation of the use of the Zoom application for online learning, especially among students, either Zoom Mobile or the desktop version of Zoom.

2. Questionnaires

This questionnaire was distributed online using Google Form, with a Likert scale score.

3. Interview

Online interviews with STMIK Nusa Mandiri students regarding the Zoom application.

4. Literature study

Literature studies are obtained from various sources such as books, journals, and related research.

The research instrument in the questionnaire was processed according to the criteria or construct used in (Rahayu, Budiyanto, \& 
Palyama, 2017) and (Hendikawati \& Hidayati, 2019), can be seen below:

Table 2. Construction Indicator Variables

\begin{tabular}{|c|c|c|}
\hline $\begin{array}{l}\mathbf{N} \\
\mathbf{0} .\end{array}$ & Construct & Indicator Variables \\
\hline \multirow{4}{*}{1} & \multirow{4}{*}{$\begin{array}{c}\text { Perceived } \\
\text { Usefulness (PU) }\end{array}$} & PU1 = Faster \\
\hline & & $\begin{aligned} \text { PU2 } & =\text { Increase } \\
& \text { Productivity }\end{aligned}$ \\
\hline & & PU3 = Effective \\
\hline & & PU4 = Helpful \\
\hline \multirow{4}{*}{2} & \multirow{4}{*}{$\begin{array}{l}\text { Perceived Ease of } \\
\text { Use (PEU) }\end{array}$} & $\begin{array}{c}\text { PEU1 = Easy to } \\
\text { Learn }\end{array}$ \\
\hline & & $\begin{array}{c}\text { PEU2 = Easy to } \\
\text { Use }\end{array}$ \\
\hline & & $\begin{aligned} \text { PEU3 = Easy to } \\
\text { Understand }\end{aligned}$ \\
\hline & & PEU4 = Flexible \\
\hline \multirow{4}{*}{3} & \multirow{4}{*}{$\begin{array}{l}\text { Behavioral Intention } \\
\text { to Use (BIU) }\end{array}$} & $\begin{aligned} \text { BIU1 = } & \text { Use } \\
& \text { Anytime }\end{aligned}$ \\
\hline & & $\begin{array}{c}\text { BIU2 }=\text { Continue } \\
\text { to Use }\end{array}$ \\
\hline & & $\begin{array}{l}\text { BIU3 = Intention } \\
\text { to Use Steadily }\end{array}$ \\
\hline & & $\begin{array}{c}\text { BIU4 = Hope to } \\
\text { Use }\end{array}$ \\
\hline \multirow{2}{*}{4} & \multirow{2}{*}{$\begin{array}{l}\text { Actual System Use } \\
\text { (AU) }\end{array}$} & $\begin{aligned} \text { AU1 } & =\text { Frequency } \\
& \text { of Use }\end{aligned}$ \\
\hline & & $\begin{aligned} \text { AU2 }= & \text { Duration } \\
& \text { of Use }\end{aligned}$ \\
\hline
\end{tabular}

Based on the variables used, a hypothesis is formed in this study as follows:

H1: Effects of Perceived Usefulness, Perceived Ease of Use, Behavioral Intention to Use on Actual System Usage

H2: Effect of Perceived Usefulness on Actual System Usage

H3: Effect of Perceived Ease to Use on Actual System Usage

H4: Effects of Behavioral Intention to Use on Actual System Usage

\section{Data analysis technique}

In analyzing this quantitative data using SPSS Version 24. The terms and methods in analysis can be seen according to the reference (Adminspssstatistik, 2016) and (Raharjo, 2019).

\section{Descriptive Statistics}

In this study, descriptive statistics are used to provide an overview of the demographics of the research respondents' data to determine the real frequency distribution which shows the mean, range, mean, standard deviation, and percentage in tabular form.

2. Test Instruments

a. Validity Test

This test uses the Pearson Correlation formula. Under the condition :

- If the calculated r-count > r-table, then the questionnaire question item is declared valid. - If the value of r-count < r-table, then the item on the questionnaire is declared invalid.

b. Reliability Test

Decision making in this reliability test using Cronbach's Alpha with the following provisions:

- If Cronbach's Alpha value > r-table, the questionnaire is declared reliable or consistent.

- If Cronbach's Alpha value < r-table, then the questionnaire is declared unreliable or inconsistent.

3. Hypothesis Testing

a. Multiple Linear Regression

Before the regression test, performed several test conditions with SPSS including the Normality test, the Multicollinearity test, and the Heteroscedasticity test.

- Normality test provided that if the significance value (Sig.) If more than $a=0.05$ then the data is normally distributed, and vice versa.

- Multicollinearity test provided that if the tolerance value is $>0.10$ or the VIF value $<10.00$, multicollinearity does not occur, and vice versa.

- Heteroscedasticity test provided that if the plot does not have a wavy spreading pattern, there is no symptom of heteroscedasticity, and vice versa.

Based on the 3 independent variables used, the general equation for multiple linear regression is obtained (Hunaifi, 2018):

$Y=a+b 1 \mathrm{PU}+b 2 \mathrm{PEU}+b 3 \mathrm{BIU}$

Where :

$a=$ Constant

$b 1=$ PU (perceived usefulness) multiple regression coefficients

$b 2=$ PEU (perceived ease of use) multiple regression coefficients

$b 3=$ BIU's (behavioral intention to use) multiple regression coefficients

b. Simultaneous Significance Test (F-Test)

F-test is done by comparing F-count with Ftable, if F-count $>$ from F-table, (Ho is rejected Ha is accepted) then the model is significant or can be seen in the significance column on And vice versa if F-count $<$ F-table, then the model is not significant. 
c. Partial Significance Test (T-Test)

This test can be done by comparing the t-count with the t-table or by looking at the significance column of the SPSS results for each $t$ count, the T-test process is identical to the F-test.

4. Variable Technology Acceptance Model (TAM) According to Venkatesh and Davis, the Technology Acceptance Model (TAM) or better known as the TAM model adopts the Theory of Reasoned Action (TRA) to predict the acceptance and usefulness of information technology or IT (Ilmi, Liyundira, \& Rachmawati, 2020). Here we will conclude in table form whether the hypothesis is accepted or not from the results of the F test and T-test, namely the influence relationship between variables of Perceived Usefulness, Perceived Ease to Use, Behavioral Intention to Use and Actual System Usage.

\section{RESULTS AND DISCUSSION}

\section{Descriptive Statistics}

Questionnaire data processing with the score of each question item processed using IBM SPSS version 24 can be seen from the following figure:

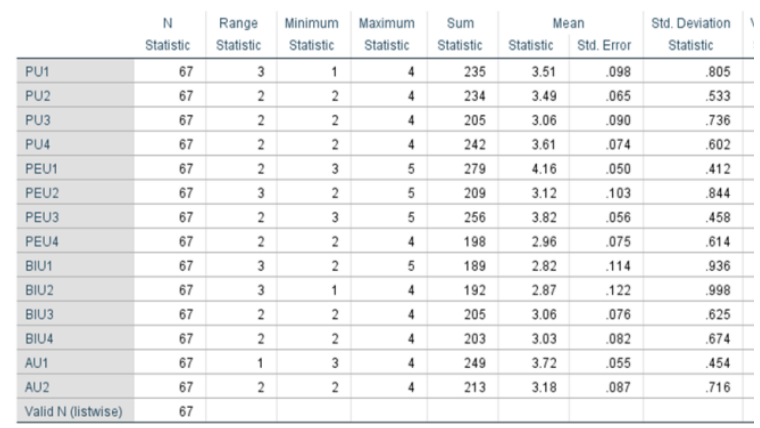

Figure 2. Descriptive Statistics

Figure 2 shows that $\mathrm{N}$ or the number of data for each valid variable is 67. Perceived Usefulness-PU shows the filling of the PU1 questions in the form of a mean value of 3.51 with a low deviation close to zero below 1, namely 0.805 . PU2 is good in the form of a mean value of 3.49 with a deviation of 0.533 . PU3 is sufficient in the form of a mean value of 3.06 with a deviation of 0.736 . PU4 is good in the form of a mean value of 3.61 with a deviation of 0.602 .

Perceived Ease to Use-PUE, Behavioral Intention to Use-BIU, and Actual System Usage-AU also show sufficient to very good values. Based on the overall results of the questions, the level of deviation is low below 1 , and filling with a minimum value is sufficient, which means that the questionnaire is evenly distributed and has a positive opinion of the acceptance of Zoom.

\section{Test Instruments}

1. Validity Test

The results of the validity test of the r-count value are greater than the $r$-table, indicating that all the items in the questionnaire are declared valid. The overall results of the validity test can be seen in the following table 3 :

Table 3. Validity Test Results with Pearson Correlations

\begin{tabular}{cccl}
\hline Variable & $\begin{array}{c}\text { r- } \\
\text { Count }\end{array}$ & $\begin{array}{c}\text { r- } \\
\text { Table }\end{array}$ & Result \\
\hline $\begin{array}{c}\text { Perceived } \\
\text { Usefulness } \\
\text { (PU) }\end{array}$ & & & \\
\hline PU1 & 0,527 & 0,317 & Valid \\
\hline PU2 & 0,591 & 0,317 & Valid \\
\hline PU3 & 0,676 & 0,317 & Valid \\
\hline PU4 & 0,598 & 0,317 & Valid \\
\hline Perceived Ease \\
of Use (PEU) & & & \\
\hline PEU1 & 0,363 & 0,317 & Valid \\
\hline PEU2 & 0,851 & 0,317 & Valid \\
\hline PEU3 & 0,701 & 0,317 & Valid \\
\hline PEU4 & 0,647 & 0,317 & Valid \\
\hline
\end{tabular}

Behavioral

Intention to

Use (BIU)

\begin{tabular}{llll}
\hline BIU1 & 0,777 & 0,317 & Valid \\
\hline BIU2 & 0,732 & 0,317 & Valid \\
\hline BIU3 & 0,726 & 0,317 & Valid \\
\hline BIU4 & 0,453 & 0,317 & Valid
\end{tabular}

Actual System

Use (AU)

\begin{tabular}{cccc}
\hline AU1 & 0,696 & 0,317 & Valid \\
\hline AU2 & 0,882 & 0,317 & Valid \\
\hline
\end{tabular}

\section{Reliability Test}

The results of the reliability test, The Cronbach's Alpha value is greater than the r-table, this indicates that all items in the questionnaire are declared reliable. The overall results of the reliability test are often within the following table 4:

Table 4. Reliability Test Results with Cronbach's 


\begin{tabular}{|c|c|c|c|}
\hline $\begin{array}{r}\text { Alp } \\
\text { Variable }\end{array}$ & $\begin{array}{c}\text { Cronbach's } \\
\text { Alpha }\end{array}$ & $\begin{array}{c}\text { r- } \\
\text { Table } \\
\end{array}$ & Result \\
\hline $\begin{array}{l}\text { Perceived } \\
\text { Usefulness } \\
(\mathrm{PU})\end{array}$ & 0,409 & 0,317 & Reliable \\
\hline $\begin{array}{l}\text { Perceived } \\
\text { Ease of Use } \\
(\mathrm{PEU})\end{array}$ & 0,598 & 0,317 & Reliable \\
\hline $\begin{array}{l}\text { Behavioral } \\
\text { Intention to } \\
\text { Use (BIU) }\end{array}$ & 0,700 & 0,317 & Reliable \\
\hline $\begin{array}{l}\text { Actual } \\
\text { System Use } \\
(\mathrm{AU})\end{array}$ & 0,476 & 0,317 & Reliable \\
\hline
\end{tabular}

\section{Hypothesis Testing}

1. Multiple Linear Regression

a. Normality Test

\begin{tabular}{|llr}
\multicolumn{2}{|c}{ One-Sample Kolmogorov-Smirnov Test } \\
& & $\begin{array}{r}\text { Unstandardiz } \\
\text { ed Residual }\end{array}$ \\
\hline $\mathrm{N}$ & \multicolumn{1}{c}{ Mean } & 67 \\
\cline { 2 - 3 } Normal Parameters $^{\mathrm{a}, \mathrm{b}}$ & Std. Deviation & .67521972 \\
\hline Most Extreme Differences & Absolute & .078 \\
\cline { 2 - 3 } & Positive & .052 \\
\cline { 2 - 3 } & Negative & -.078 \\
\hline Test Statistic & & .078 \\
\hline Asymp. Sig. (2-tailed) & & $.200^{\text {c,d }}$ \\
\hline
\end{tabular}

Figure 3. Normality Test Results

Based on the output data from Figure 3, it is known that the Asiymp. Sig. (2-tailed) of 0.200 is greater than 0.05 , so according to the basis for the decision-making of the Kolmogorov-Smirnov normality test, it can be concluded that the data is normally distributed.

b. Multicollinearity Test

\begin{tabular}{|c|c|c|c|c|c|c|c|c|}
\hline & & & & efficients ${ }^{a}$ & & & & \\
\hline & & Unstandardi & Coefficients & $\begin{array}{l}\text { Standarcized } \\
\text { Coefficientsts }\end{array}$ & & & Collinearity & tatitistics \\
\hline Mod & & B & Std. Error & Beta & $t$ & Sig. & Tolerance & VIF \\
\hline 1 & (Constant) & 2.845 & .869 & & 3.275 & .002 & & \\
\hline & Tot_PU & .086 & .056 & .157 & 1.540 & .129 & .774 & 1.29 \\
\hline & Tot_PEU & .003 & .061 & .005 & .050 & .960 & .699 & 1.43 \\
\hline & Tot_BlU & .246 & .046 & .615 & 5.314 & .000 & .603 & 1.65 \\
\hline
\end{tabular}

Figure 4. Multicollinearity Test Results

Based on the figure above, the "Collinearity Statistics" section shows that the Tolerance value of each variable is greater than 0.10 and the VIF value is less than 10.00 . So it is concluded that there is no multicollinearity, which means that there is no relationship between the independent variables in the regression model.

c. Heteroscedasticity Test

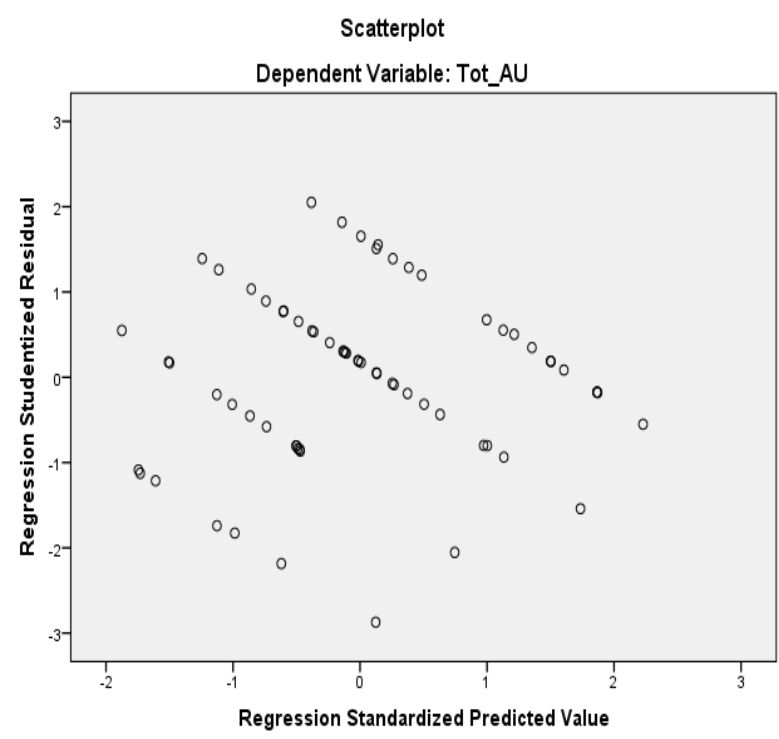

Figure 5. Heteroscedasticity Test Result

Based on the Scatterplots image, it can be seen that the scatter data points are above and below or around the number 0 , the dots do not collect only above or below, and the spread does not form a wavy pattern then narrows and widened again. Thus it can be concluded that heteroscedasticity does not occur so that a good regression model can be fulfilled. Returning to the multiple linear regression equation obtained can be seen in figure 6 below:

Coefficients ${ }^{\mathrm{a}}$

\begin{tabular}{|c|c|c|c|c|c|c|}
\hline \multirow[b]{2}{*}{ Model } & & \multicolumn{2}{|c|}{ Unstandardized Coefficients } & \multirow{2}{*}{$\begin{array}{c}\text { Standardized } \\
\text { Coefficients } \\
\text { Beta }\end{array}$} & \multirow[b]{2}{*}{$t$} & \multirow[b]{2}{*}{ Sig. } \\
\hline & & B & Sta. Error & & & \\
\hline \multirow[t]{4}{*}{1} & (Constant) & 2.845 & .869 & & 3.275 & .002 \\
\hline & Tot_PU & .086 & .056 & .157 & 1.540 & .129 \\
\hline & Tot_PEU & .003 & .061 & .005 & .050 & .960 \\
\hline & Tot_BIU & .246 & .046 & .615 & 5.314 & .000 \\
\hline
\end{tabular}

a. DependentVariable: Tot_AU

Figure 6. Regression Coefficient

Based on the value of $B$ in Figure 6 , it is known that the multiple linear regression equation is:

$\mathrm{Y}=2.845+0.086 \mathrm{X} 1+(-0.03) \mathrm{X} 2+0.246 \mathrm{X} 3$

The constant is 2.845 , meaning that if Perceived Usefulness (X1), Perceived Ease of Use (X2), Behavioral Intention to Use (X3) are 0, then the Actual System Usage is 2.845. Perceived 
Usefulness (X1) variable regression coefficient is positive at 0.086, Perceived Ease of Use (X2) is negative (- 0.03) and Behavioral Intention to Use (X3) is positive at 0.246 .

\section{Simultaneous Significance Test (F-Test)}

\begin{tabular}{|c|c|c|c|c|c|c|}
\hline \multicolumn{7}{|c|}{ ANOVA $^{a}$} \\
\hline \multicolumn{2}{|c|}{ Model } & $\begin{array}{l}\text { Sum of } \\
\text { Squares }\end{array}$ & $d f$ & Mean Square & $F$ & Sig. \\
\hline \multirow[t]{3}{*}{1} & Regression & 28.954 & 3 & 9.651 & 20.207 & $.000^{b}$ \\
\hline & Residual & 30.091 & 63 & .478 & & \\
\hline & Total & 59.045 & 66 & & & \\
\hline
\end{tabular}

Figure 7. Test F Results

From Figure 7, it is obtained that the Fcount is 20.207 and the F-table (df1; df2 = 3; 63) is 2.751 with a significance level of 0.000 . This shows that Perceived Usefulness, Perceived Ease to Use, and Behavioral Intention to Use have a significant effect on the Actual System Usage of the Zoom application.

\section{Partial Significance Test (T-Test)}

In the T-test, it can be seen from the $\mathrm{T}$ value in Figure 6. Regression Coefficient. From the figure, it is obtained that the PU t-count value is 1.540 and the $\mathrm{t}$-table value is $1.998(\alpha / 2$; df residual $=0.025$; 63) means the t-count < t-table, while the significance level is 0.129 above $\alpha=0.05$. Thus partially the Perceived Usefulness variable has no significant effect on Actual System Usage.

From the PEU t-count value of -0.050 and the $\mathrm{t}$-table of 1.654 , it means that the $\mathrm{t}$-count $<\mathrm{t}$-table, while the significance level is 0.960 above $\alpha=0.05$. Thus partially the Perceived Ease of Use variable also has no significant effect on Actual System Usage.

From the BIU t-count value of 5.314 and $t$ table of 1.654 , it means that the $\mathrm{t}$-count $>\mathrm{t}$-table, while the significance level is 0.000 above $\alpha=0.05$. Thus partially the Behavioral Intention to Use variable has a significant effect on Actual System Usage.

\section{Variable Technology Acceptance Model (TAM)}

The following TAM variable will combine the results of several tests between variables that have been carried out and provide results whether the hypothesis test is accepted or rejected.
1. H1: Effects of Perceived Usefulness, Perceived Ease of Use, Behavioral Intention to Use on Actual System Usage

Based on the F-test in figure 7 shows the Fcount value of 20.21 and is greater than the Ftable 2.75 so that it shows Ho Rejected. It can be said that Perceived Usefulness, Perceived Ease of Use, and Behavioral Intention to Use have a significant effect on the Actual System Usage of the Zoom application. Also, the value is supported by the results of the constant $(a)$ multiple linear regression in table 8 of 2.85, which means that hypothesis one has a significant positive effect.

2. H2: Effect of Perceived Usefulness on Actual System Usage

Based on the T-test in figure 6, shows that the T-count value of PU is 1.54 and is smaller than the T-table of 1.998 so that it shows Ho Accepted. It can be said that Perceived Usefulness has less influence on the Actual System Usage of the Zoom application. Also, the value is supported by the results of $\mathrm{X} 1$ multiple linear regression in table 8 of 0.09 , which means that the second hypothesis has a significant positive effect.

3. H3: Effect of Perceived Ease to Use on Actual System Usage

Based on the T-test in figure 6 shows the value of the T-count PEU (-0.05) and is smaller than the T-table of 1.998 , so that shows Ho Accepted. It can be said that the Perceived Ease of Use has less influence on the Actual System Usage of the Zoom application. Also, the value is supported by the results of $\mathrm{X} 2$ multiple linear regression in table 8 of $(-$ 0.03 ), which means that the three hypotheses have a significant negative effect.

4. H4: Effects of Behavioral Intention to Use on Actual System Usage

Based on the T-test in figure 6, shows that the T-count value of BIU is 5.31 and is greater than the T-table of 1.998 so that it shows Ho Rejected. It can be said that Behavioral Intention to Use has less influence on the Actual System Usage of the Zoom application. Also, the value is supported by the results of X3 multiple linear regression in table 8 of 0.25 , which means that hypothesis four has a significant positive effect.

\section{CONCLUSIONS AND SUGGESTIONS}

\section{Conclusion}

Based on the analysis of research data that has been done, it can be concluded that the validity and reliability test shows that the questionnaire 
data obtained is valid and reliable so it is good to continue and be used in this study. While the influence between each variable, Behavioral Intention to Use is more dominant than the other variables used at 5.31, while the lowest is Perceived Ease of Use with a minus value $(-0.50)$. This means that ease of use of applications is a common practice in various types of application development industries, and this also means that the more users are interested in using it, the greater acceptance of the Zoom application for online learning.

\section{Suggestion}

From the overall results of the research conducted, the suggestions that can be given are that it is hoped that simultaneous counseling from educational institutions will be officially used and the use of the Zoom application in online learning will be beneficial during the Covid-19 pandemic. As well as in developing or researching acceptance of the use of technology, then adding more variables and indicators in the use of the TAM model, such as Attitude Toward Using or others by existing regulations.

\section{REFERENCES}

Adminspssstatistik. (2016). SPSS Statistik: Olah Data Statistik dengan Menggunakan SPSS.

Arifa, F. N. (2020). Tantangan Pelaksanaan Kebijakan Belajar Dari Rumah Dalam Masa Darurat Covid-19. INFO Singkat: Kajian Singkat Terhadap Isu Aktual Dan Strategis, 12(7), 13-18.

Hendikawati, P., \& Hidayati, N. (2019). Persepsi Mahasiswa Terhadap Sistem Aplikasi SIMPKL Pada Implementasi Kegiatan Praktek Kerja Lapangan Menggunakan Analisis TAM. Jurnal TAM (Technology Acceptance Model), 10(2), 74-82. Retrieved from http://ojs.stmikpringsewu.ac.id/index.php/J urnalTam/article/view/693

Herwatin, A., Purwaningrum, A., Dwi Suswarti, S., Maryama Alfianne, D., Aprilia, F., Rifatul Azizah, L., ... Sulistyaningsih. (2019). Antologi Pustakawan. Malang: Universitas Muhammadiyah Malang.

Hidayat, A. R., \& Junianto, E. (2017). Pengaruh Gadget Terhadap Prestasi Siswa SMK Yayasan Islam Tasikmalaya Dengan Metode TAM | Hidayat | Jurnal Informatika. Jurnal Informatika, 4(2), 163-173. Retrieved from http://ejournal.bsi.ac.id/ejurnal/index.php/ji /article/view/2096

Hunaifi, N. (2018). Penerapan Metode Tam Terhadap Penerimaan Sistem Informasi
Produksi Garment. Jurnal Informatika, 5(2), 221-227.

Ilmi, M., Liyundira, F. S., \& Rachmawati, A. (2020). Perkembangan Dan Penerapan Theory of Acceptance Model ( TAM ) Di Indonesia. Relasi: Jurnal Ekonomi, 16(2), 436-458.

Josina. (2020). Zoom Capai 300 Juta Pengguna Aktif Harian.

Oktofiyani, R., Nurmalasari, \& Anggraeni, W. (2016). Penerimaan Sistem E-Learning Menggunakan Technology Acceptance Model ( Tam ) Study Kasus Siswa / I Kelas X Di SMU Negeri 92 Jakarta. Jurnal PILAR Nusa Mandiri, 12(1), 46-53. Retrieved from http://ejournal.nusamandiri.ac.id/index.php /pilar/article/view/258

Qonita, A. A., Sulton, \& Soepriyanto, Y. (2019). Persepsi Kegunaan, Kemudahan Dan Aksebilitas Mahasiswa Fakultas Ilmu Pendidikan Angkatan 2018 Terhadap Penerapan SIPEJAR Menggunakan Model TAM (Technology Acceptance Model). Jurnal Kajian Teknologi Pendidikan, 2(2), 140-148.

Raharjo, S. (2019). SPSS Indonesia: Olah Data Statistik dengan SPSS.

Rahayu, F. S., Budiyanto, D., \& Palyama, D. (2017). Analisis Penerimaan e-Learning Menggunakan Technology Acceptance Model ( TAM ) ( Studi Kasus : Universitas Atma Jaya Yogyakarta ). JUTEI, 1(2), 85-95. https://doi.org/10.21460/jutei.2017.12.20

Ramadhani, H., \& Monalisa, S. (2017). Analisis Penerapan Sistem Informasi Pengelolaan Nilai Raport Menggunakan Metode TAM. Ilmiah Rekayasa Dan Manajemen Sistem Informasi, 3(2), 65-69.

Yusuf, M. (2017). Metode Penelitian: Kuantitatif, Kualitatif \& Penelitian Gabungan. Jakarta: Kencana. 